\begin{tabular}{l} 
DURNAI, R IS'II \\
(Rekayasa Sistem dan Teknologi Informasi) \\
Vol.1 No.2(2017) $90-98 \mid$ ISSN Media Elektronik : 2580-0760 \\
\hline
\end{tabular}

\title{
Model Sistem Penjaminan Mutu Berbasis Integrasi Standar Akreditasi BAN-PT dan ISO 9001:2008
}

\author{
Mercurius Broto Legowo ${ }^{\mathrm{a}}$, Budi Indiarto ${ }^{\mathrm{b}}$ \\ a Program Studi Sistem Informasi, Fakultas Teknologi Informasi, Perbanas Institute-Jakarta, mercurius@perbanas.id \\ ${ }^{\mathrm{b}}$ Program Studi Teknik Informatika, Fakultas Teknologi Informasi, Perbanas Institute-Jakarta, budi.indiarto@perbanas.id
}

\begin{abstract}
Quality Assurance System for Higher Education is absolutely necessary to guarantee the quality of education, especially for the study program. ISO 9001: 2008 is a standard for quality management systems and Accreditation of BAN-PT is a standard for quality academic process improvement for higher education. Problems will rise when the two sets of documents are to be integrated into a model that forms the quality assurance system. This is due to differences in language, structure, and details of the two sets of documents. Accordingly, the purpose of this research is to develop a model of quality assurance system by conducting integration of accreditation of BAN-PT and ISO 9001: 2008. The methods that are used to integrate the two documents in this research are comparative method, mapping method and harmonization model. The expected results of this study is to indicate the efficiency of ISO clauses and requirements reuse in the implementation of BAN-PT accreditation and the effectiveness of an implementation of BAN-PT Accreditation in adopting ISO processes. This model would be an extremely useful tool for ISO-certified higher education that plans to implement Accreditation of BAN-PT.
\end{abstract}

Keywords: Quality Assurance System, Integrated Model, ISO 9001:2008, Accreditation Standard from BAN-PT

\begin{abstract}
Abstrak
Sistem Penjaminan Mutu untuk Perguruan Tinggi mutlak diperlukan untuk menjamin kualitas pendidikan, khususnya program studi. ISO 9001: 2008 adalah standar untuk sistem manajemen mutu dan Akreditasi BAN-PT merupakan standar untuk peningkatan proses akademik yang berkualitas untuk perguruan tinggi. Permasalahan akan timbul bila kedua set dokumen tersebut akan diintegrasikan ke dalam suatu model sistem penjaminan mutu. Hal ini disebabkan adanya perbedaan bahasa, struktur, dan rincian kedua set dokumen tersebut. Tujuan dari penelitian ini adalah untuk mengembangkan model sistem penjaminan mutu dengan melakukan integrasi akreditasi BAN-PT dan ISO 9001: 2008. Metode Yang digunakan dalam mengintegrasikan dua dokumen dalam penelitian ini adalah metode komparatif, metode pemetaan dan model harmonisasi. Hasil yang diharapkan dari penelitian ini menunjukkan efisiensi penggunaan kembali klausul dan persyaratan ISO dalam penerapan akreditasi BAN-PT dan efektifitas suatu penerapan akreditasi BAN-PT dalam proses adopsi ISO. Model ini akan menjadi alat yang sangat berguna untuk perguruan tinggi bersertifikat ISO yang berencana menerapkan Akreditasi BAN-PT.
\end{abstract}

Kata kunci : Sistem Penjaminan Mutu, Model Integrasi, ISO 9001:2008, Standar Akreditasi BAN-PT

(C) 2017 Jurnal RESTI

\section{Pendahuluan}

Sesuai dengan Undang-Undang RI Nomor 20 Tahun 2003, PP RI Nomor 19 tahun 2005 dan peraturan perundang-undangan lainnya serta kecenderungan perkembangan kebijakan tentang sendiri maupun secara bersama-sama yang pada pendidikan tinggi yang menekankan pada mutu dan hakikatnya untuk menjamin mutu penyelenggaraan akuntabilitas publik institusi perguruan tinggi dan pendidikan tinggi. Kegiatan tersebut adalah program studi maka diperlukan akreditasi program Akreditasi Perguruan Tinggi (oleh Pemerintah atau studi.[2] Akreditasi ini meliputi semua aspek material BAN-PT), dan Penjaminan Mutu (Quality Assurance). termasuk praktek-praktek terbaik dalam proses Kedua kegiatan tersebut bekerja secara sinergis,

akreditasi khususnya pada program studi sesuai standar nasional pendidikan yang berlaku secara internasional (international best practices).

Terdapat beberapa kegiatan yang mesti dilakukan baik 
menggunakan data dan standar yang sama, saling pembelajaran jarak jauh [10]. Terdapat pula penelitian mendukung dalam sebuah sistem yang disebut yang membuat rancang bangun aplikasi perangkat Sistem Penjaminan Mutu Perguruan Tinggi (SPM- lunak terkait Standar BAN-PT [11\}. Penelitian lain PT)[1]. Akreditasi BAN-PT adalah Sistem Penjaminan terkait integrasi model yaitu dengan membuat unified Mutu Eksternal (SPME)[2]. SPME adalah kegiatan model dengan integrasi CMMI dan ISO 9001 [12], sistemik penilaian kelayakan program studi dan/atau seperti yang akan dilakukan dalam penelitian ini, hanya perguruan tinggi oleh BAN-PT atau lembaga mandiri nantinya integrasi antara akreditasi BAN-PT dengan di luar perguruan tinggi yang diakui pemerintah, ISO 9001:2008. Penelitian ini yang merupakan untuk mengawasi penyelenggaraan pendidikan tinggi penelitian produk terapan adalah studi untuk untuk dan atas nama masyarakat sebagai bentuk mengembangkan suatu model Sistem Penjaminan Mutu akuntabilitas publik. Penjaminan mutu melalui Sistem dengan melakukan integrasi akreditasi BAN-PT dan Manajemen Mutu ISO 9001:2008[3] telah berkembang ISO 9001: 2008. Pendekatan penelitian yang pesat dan menyentuh pada hampir semua jenis aktivitas digunakan adalah penelitian kualitatif [13] dengan produksi dan jasa termasuk institusi pendidikan.[4] teknik pengumpulan data dan melakuan analisa Penjaminan mutu yang ideal harus difokuskan pada Tri kualitatif [14] berupa diskusi kelompok terarah serta Dharma Perguruan Tinggi, sistem internal dan melakukan uji validitas model.

pemenuhan sistem nasional seperti akreditasi BAN-PT. ISO 9001:2008 adalah Sistem Penjaminan Mutu Internal (SPMI) yaitu kegiatan sistemik penjaminan mutu pendidikan tinggi di perguruan tinggi oleh perguruan tinggi bersangkutan (Internally driven) melalui Lembaga Penjaminan Mutu (LPM), yang bertujuan untuk mengawasi penyelenggaraan pendidikan tinggi oleh oleh perguruan tinggi secara berkelanjutan (continuous improvement)[1]. Permasalahan akan timbul ketika perguruan tinggi yang telah memiliki sertifikasi ISO 9001:2008 akan

Hasil yang diharapkan dari penelitian ini menunjukkan efisiensi penggunaan kembali klausa dan persyaratan ISO dalam penerapan akreditasi BAN-PT dan efektifitas suatu penerapan akreditasi BAN-PT dalam mengadopsi ISO 9001:2008. Model ini akan menjadi alat yang sangat berguna untuk perguruan tinggi bersertifikat ISO yang berencana menerapkan Akreditasi BAN-PT.

\section{Tinjauan Pustaka}

melaksanakan akreditasi program studi berdasarkan Penjaminan Mutu Perguruan Tinggi merupakan suatu BAN-PT, dikarenakan kedua kerangka model ini konsep multi-stakeholders[2]. Sistem Penjaminan Mutu terkait dengan penjaminan mutu. ISO adalah standar bagi Perguruan Tinggi mutlak diperlukan untuk mutu manajemen bagi organisasi[3] sedangkan menjamin kualitas pendidikan, khususnya program Akreditasi BAN-PT adalah standar mutu studi yang dimilikinya.

penyelenggaraan pendidikan pada program studi di perguruan tinggi[2]. Namun ternyata beberapa klausa 2.1 Standar Akreditasi Program Studi BAN-PT standar ISO bisa digunakan kembali ketika melaksanakan akreditasi program studi BAN-PT.

Akreditasi program studi adalah proses evaluasi dan penilaian secara komprehensif atas komitmen Berdasarkan permasalahan inilah maka diperlukan program studi terhadap mutu dan kapasitas metode-metode untuk mengintegrasikan kedua penyelenggaraan program tri-dharma perguruan dokumen terkait penjaminan mutu perguruan tinggi tinggi, untuk menentukan kelayakan program tersebut, selanjutnya diimplementasikan dalam suatu akademiknya[1].

model sistem penjaminan mutu berbasis integrasi akreditasi BAN-PT dan ISO 9001:2008. Metode untuk melakukan integrasi didasarkan pada penelitian sebelumnya. Dalam penelitian-penelitian terdahulu ini terkait bagaimana melakukan integrasi model CMMI yang merupakan standar mutu pengembangan perangkat lunak dengan ISO 9001:2008 untuk standar mutu manajemen digunakan beberapa integrasi tersebut, diantaranya adalah metode komparasi [5], metode Process Mapping [6], serta metode Harmonisasi Model[7] Penelitian terkait Sistem Penjaminan Mutu telah banyak dilakukan oleh beberapa peneliti sebelumnya. Penelitian dengan membandingkan SMM ISO 9001:2008, Standard BANPT dan Total Quality Management di UIN Malang [8]. Studi lain tentang peningkatan mutu proses perguruan tinggi melalui sistem ISO 9001 [9], serta studi terkait pengaruh pencapaian ISO 9001:2000 terhadap

Tabel 1.Standar Akreditasi BAN-PT

\begin{tabular}{|c|c|}
\hline Standar Akreditasi & Deskripsi \\
\hline Standar 1 & $\begin{array}{l}\text { Visi, Misi, tujuan dan sasaran serta } \\
\text { strategi pencapaian }\end{array}$ \\
\hline Standar 2 & $\begin{array}{l}\text { Tata Pamong, Kepemimpinan, sistem } \\
\text { pengelolaan, dan penjaminan mjutu }\end{array}$ \\
\hline Standar 3 & Mahasiswa dan Lulusan \\
\hline Standar 4 & Sumber daya Manusia \\
\hline Standar 5 & $\begin{array}{l}\text { Kurikulum, Pembelajaran dan suasana } \\
\text { akademik }\end{array}$ \\
\hline Standar 6 & $\begin{array}{l}\text { Pembiayaan, sarana dan prasarana serta } \\
\text { sistem informasi }\end{array}$ \\
\hline Standar 7 & $\begin{array}{l}\text { Penilaian dan pelayanan/pengabdian } \\
\text { kepada masayarakat dan kerjasama }\end{array}$ \\
\hline
\end{tabular}

BAN-PT adalah lembaga yang memiliki kewenangan untuk mengevaluasi dan menilai, serta menetapkan status dan peringkat mutu program studi berdasarkan standar mutu yang telah ditetapkan. 
Standar akreditasi program studi sarjana mencakup standar tentang komitmen program studi sarjana terhadap kapasitas institusional (institutional capacity) dan komitmen terhadap efektivitas program pendidikan (educational effectiveness), yang dikemas dalam tujuh standar akreditasi. Asesmen kinerja program studi sarjana didasarkan pada pemenuhan tuntutan standar akreditasi. Tabel 1 menunjukkan tuntutan Standar Mutu yang harus dipenuhi dalam standar akreditasi BAN-PT.

\subsection{Sistem Manajemen Mutu ISO 9001:2008}

International Standard Organization (ISO) adalah suatu badan yang mengatur sertifikasi atau mengesahkan suatu standar[3]. Sedangkan ISO 9001:2008 [3] merupakan suatu standar internasional untuk sistem manajemen mutu (kualitas)..

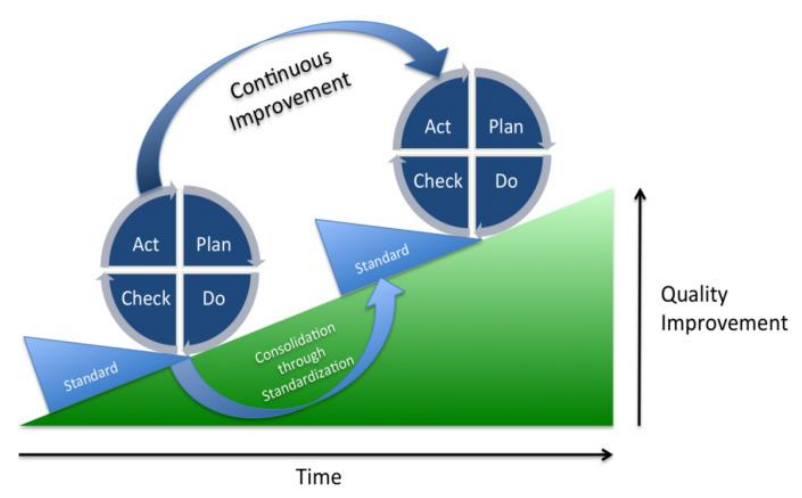

Gambar 1. Perbaikan yang berkesinambungan ISO 9001: 2008

ISO 9001:2008 menetapkan persyaratan-persyaratan dan rekomendasi untuk desain dan penilaian dari suatu sistem manajemen mutu, yang bertujuan untuk menjamin bahwa organisasi akan memberikan produk (barang atau jasa) yang memenuhi persyaratan yang ditetapkan. Sistem ISO 9001:2008 fokus pada efektivitas proses continual improvement dengan pilar utama denganpola piker utama PDCA ( Plan- DoCheck-Action ), dimana dapat dijelaskan seperti pada Gambar 1.Persayaratan Sistem manajemen Mutu ISO 9001 : 2008, berdasarkan dari SNI-ISO 9001:2008 yang diterbitkan oleh Badan Standar Nasional Indonesia, maka sistem mutu manajemen ISO memiliki bagian isi dan penjelasannya dapat dilihat pada Tabel 2 .

\subsection{Metode Integrasi Model Sistem Penjaminan Mutu}

Untuk melakukan integrasi standar Akreditasi BAN-PT dan standar ISO 9001:2008, maka dilakukan dengan cara yang sama dari penelitian-penelitian terdahulu ketika melakukan integrasi standar CMMI sebagai standar maturity pengembangan perangkat lunak dengan standar mutu ISO 9001:2008, yaitu :

a. Metode komparasi oleh Paulk [5], memahami dan membandingkan proses-proses yang terkait dengan sistem penjaminan mutu dari kedua standar tersebut, dengan tujuan melakukan sinergi guna mengembangkan suatu model penjaminan mutu berbasis integrasi Akreditasi BAN-PT dan ISO 9001:2008. Kekurangan dari model komparasi ini adalah adanya sifat obyektivitas dalam melakukan komparasi antara kedua set dokumen tersebut.

Tabel 2 .Klausa dan Persyaratan ISO 9001:2008

\begin{tabular}{|c|c|c|}
\hline Bagian & Nama Klausa & Isi Klausa \\
\hline 1 & Ruang Lingkup & Umum dan aplikasi \\
\hline 2 & Acuan Normatif & $\begin{array}{l}\text { Masalah Acuan } \\
\text { pemakaian dokumen }\end{array}$ \\
\hline 3 & Istilah dan definisi & $\begin{array}{l}\text { Istilah dan definisi yang } \\
\text { di ISO 9001:2008 }\end{array}$ \\
\hline 4 & $\begin{array}{l}\text { Sistem Manajemen } \\
\text { Mutu }\end{array}$ & $\begin{array}{l}\text { Persyaratan Umum dan } \\
\text { persyaratan dokumentasi }\end{array}$ \\
\hline 5 & $\begin{array}{l}\text { Tanggung Jawab } \\
\text { Manajemen }\end{array}$ & $\begin{array}{l}\text { Komitmen Manajemen, } \\
\text { Fokus pada pelanggan, } \\
\text { Kebijakan Mutu, } \\
\text { Perencanaan, Tanggung } \\
\text { Jawab dan Wewenang, } \\
\text { Tinjauan Manajemen }\end{array}$ \\
\hline 6 & $\begin{array}{l}\text { Sumber Daya } \\
\text { Manusia }\end{array}$ & $\begin{array}{lr}\text { Umum, } & \text { Kompetensi, } \\
\text { Pelatihan } & \text { dan } \\
\text { Keasadaran, } & \text { Prasarana } \\
\text { dan Lingkungaan Kerja }\end{array}$ \\
\hline 7 & Realisasi Produk & $\begin{array}{l}\text { Perencanaan Realisasi } \\
\text { Produk,proses yang } \\
\text { berkenaan dengan } \\
\text { pelanggan, Disain dan } \\
\text { pengembangan, } \\
\text { Pembelian, Produksi dan } \\
\text { penyediaan } \\
\text { jasapengendalian } \\
\text { peralatan dan pemantauan } \\
\text { dan pengukuran }\end{array}$ \\
\hline 8 & $\begin{array}{l}\text { Pengukuran, Analisa } \\
\text { dan Perbaikan }\end{array}$ & $\begin{array}{l}\text { Umum, Pemantauan dan } \\
\text { pengukuran, } \\
\text { Pengendalian produk } \\
\text { yang tidak sesuai, Analisa } \\
\text { data dan perbaikan }\end{array}$ \\
\hline
\end{tabular}

b. Metode Mapping oleh Mutafelija and Stromberg, [6], didasarkan pada hasil komparasi sebelumnya. Bertujuan untuk memudahkan klausa-klausa dari ISO mana saja yang terkait dengan standar Akreditasi BAN-PT. Kelemahannya bahwa kaitan antar kedua set dokumen tidak didasarkan pada tujuan tertentu dan mengkaitkan proses yang ada secara subyektif.

c. Metode Harmonisasi model Pardo et al [7]. Metode ini mempunyai tujuan untuk mengetahui interseksi dari kedua dokumen, serta dokumen yang tidak bisa bersinergi dari dokumen Akreditasi BAN-PT dengan dokumen ISO 9001:2008. Kelemahan dari metode ini yaitu metode ini dilakukan bergantung dari kedua metode sebelumnya.

\subsection{Penelitian Terkait Terdahulu}

Pada beberapa penelitian sebelumnya, peneliti melakukan integrasi model untuk model CMMI dan ISO 9001:2008 pada kualitas kematangan dalam 
pengembangan perangkat lunak (Paulk, 1995; penelitian kompetitif yang tergolong dalam kelompok Mutafelija dan Stromberg, 2009; Pardo et al, 2012). penelitian mandiri yang diarahkan untuk menciptakan Metode intrgrasi dari ketiga penelitian tersebut akan inovasi dan pengembangan iptek sosbud (Penelitian digunakan dalam penelitian ini. Penelitian lain oleh Terapan). Pada penelitian ini dilakukan tahapan mulai Ronald Reinaldi dkk (2013) bertujuan untuk dari pengumpulan data awal, pengolahan data awal, merancang dan membangun perangkat lunak yang metode/model yang diusulkan, ekperimen dan mampu mengakomodasi pendokumentasian dan pengujian model serta evaluasi dan validasi hasil. rekapitulasi laporan kegiatan penelitian, pelayanan Penelitian Terapan ini menggunakan pendekatan secara masyarakat, dan kerjasama dengan mengacu pada kualitatif. Hasil integrasi yang telah dilakukan kebutuhan penyusunan portofolio akreditasi BAN- dijadikan bahan melakukan Focus Group Discussion PT standar tujuh yaitu standar penelitian, pelayanan dengan Dekan dan Para Kaprodi, yang bertujuan masyarakat, dan kerjasama. Pada penelitian ini menyamakan persepsi terhadap model sistem dilakukan dengan tujuan untuk membuat model dan penjaminan mutu yang berbasis integrasi ini. Untuk mengembangkan sistem informasi penjaminan mutu mengetahui validitas model maka dilakukan Uji perguruan tinggi berbasis integrasi standar Akreditasi Validitas, disebut juga dengan uji obyektivitas BAN-PT dan ISO 9001:2008.

\subsection{Kerangka Berpikir} penelitian. Penelitian dikatakan obyektif apabila disepakati banyak orang. Uji ini diverifikasi oleh Assesor BAN-PT dan Auditor ISO.

Pada penelitian ini dikembangkan sebuah Kerangka Berpikir yang menghubungkan masalah yang muncul dengan pendekatan metode-metode yang relevan untuk pemecahan masalah, seperti yang ada pada Gambar 2

\section{Hasil dan Pembahasan}

\subsection{Hasil Integrasi}

\section{Metode Komparasi:}

Sebagai contoh, dalam penelitian ini akan dilakukan komparasi standard akreditasi -1 dan standar akreditasi

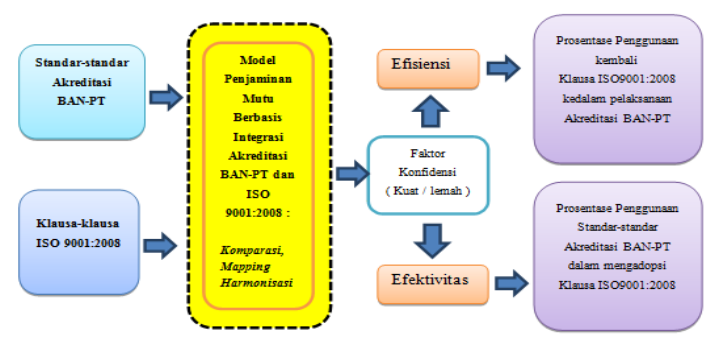

Gambar 2. Kerangka Berpikir Model Sistem Penjaminan Mutu Berbasis Integrasi Akreditasi BAN-PT dan ISO 9001:2008

Standar Akreditasi BAN-PT adalah dokumen yang bertujuan untuk peningkatan standar mutu program studi perguruan tinggi [3] sedangkan ISO 9001:2008 meruoakan standar mutu proses manajemen suatu organisasi[4]. Apabila suatu perguruan tinggi telah bersertifikasi ISO maka akan timbul permasalahan bagaimana melakukan integrasi antara kedua dokumen standar mutu tersebut, sehingga tercipta suatu model sistem informasi penjaminan mutu berbasis intergrasi Akreditasi BAN-PT dan ISO 9001:2008. Metode komparasi[5], metode mapping [6], dan harmonisasi model[7] selanjutnya digunakan dalam melakukan intergrasi dari kedua dokumen standar mutu tersebut. Faktor konfidensi digunakan untuk menentukan efisensi dan efektivitas integrasi kedua model standar mutu tersebut yang juga merupakan tujuan akhir penelitian ini.

\section{Metodologi Penelitian}

Metode penelitian yang digunakan pada penelitian ini adalah penelitian produk terapan, yakni suatu model
-4, dimana didasarkan atas kekhususan yang dimiliki oleh kedua standar ini.

\section{SA - 1 VISI, MISI, TUJUAN DAN SASARAN, SERTA STRATEGI PENCAPAIAN}

Standar ini adalah acuan keunggulan mutu penyelenggaraan dan strategi program studi untuk meraih masa depan. Terkait Visi yang baik (EP-1) dan Misi Prodi yang terkait dengan (EP-2), maka sesuai ISO terdapat dalam manual mutu yang tidak dimiliki oleh Prodi. Visi dan misi prodi ada dalam dokumen Evaluasi Diri. Tujuan dan sasaran yang baik adalah yang realistis, unik, terfokus, dan keberhasilan pelaksanaannya dapat diukur dengan rentang waktu yg jelas dan relevan terhadap misi dan visi (EP-1.3) sesuai dengan Klausa ISO (5.1). Sedangkan Visi, misi, tujuan, dan sasaran yang baik harus menjadi milik, dipahami dan didukung oleh seluruh pemangku kepentingan program studi hanya ada dalam Manual Mutu Institusi. Strategi pencapaian sasaran yang baik ditunjukkan dengan bukti tertulis dan fakta di lapangan(EP-1.5) dapat disesuaikan dengan persyaratan ISO (5.1) tentang penetapan sasaran mutu

\section{SA - 4 SUMBER DAYA MANUSIA}

Standar ini adalah acuan keunggulan mutu sumber daya manusia yang andal dan mampu menjamin mutu penyelenggaraan program studi. Secara keseluruhan Standars Akrditasi - 4 (SA-4) dapat mengadopsi Klausa 6.0 dari ISO 9001:2008, yaitu tentang Pengelolaan Sumber Daya, khususnya di klausa 6.2 Sumber Daya Manusia. Pada (EP-4.1) dapat 
disesuaikan dengan klausa ISO (6.1) agar penyediaan sumber daya sesuai penerapan Sistem Manajemen Mutu dan meningkatkan kepuasan mahasiswa sebagai pelanggan, dan klausa (6.2.1)dimana persayaratannya bahwa staf harus memerlukan ketrampilan. Pada (EP4.2) sesuai dengan klausa (6.2) khususnya (6.2.2) yaitu Kompetensi, pelatihan dan keasadaran SDM. Dalam EP-4.3 Terkait Reputasi dan keluasan jejaring dosen dalam bidang akademik dan profesi (EP-4.3) juga sesuai dengan klausa (6.2.2). Elemenen Penliaian (EP4.4) disesuaikan dengan klausa ISO (6.2.1) dan (EP4.5) bisa disesuaikan dengan klausa (6.2.2) serta (5.4.2) yang harus sesuai dengan perencanaan sesuai sasaran mutu. Sedangkan, (EP-4.6) sistem monitoring dan evaluasi disesuaikan dengan klausa $\operatorname{ISO}(6.2 .2)$ terkait evaluasi keefektifan dan pemeliharaan rekaman dan klausa (8.2.3) Pemantauan dan pengukuran proses.

\section{Metode Mapping:}

Berdasarkan hasil komparasi maka dibuat mapping seperti Mutafelija dan Stromberg (2000) untuk mapping CMMI kedalam ISO 9001 atau sebaliknya.

Tabel 3.Mapping Standar Akreditasi BAN-PT ke ISO 900:2008

\begin{tabular}{|c|c|c|c|}
\hline $\begin{array}{l}\text { Standar } \\
\text { Akreditasi }\end{array}$ & $\begin{array}{l}\text { Elemen } \\
\text { Penilaian }\end{array}$ & Deskripsi & $\begin{array}{l}\text { Klausa } \\
\text { ISO } \\
\text { 9001:2008 } \\
\end{array}$ \\
\hline \multirow[t]{6}{*}{ SA-1 } & & $\begin{array}{l}\text { Visi,Misi dan } \\
\text { Sasaran serta } \\
\text { Strategi } \\
\text { Pencapaian }\end{array}$ & \\
\hline & EP-1.1 & $\begin{array}{l}\text { Visi Yang baik } \\
\text { konsisten } \\
\text { dengan visi PT }\end{array}$ & $\begin{array}{l}\text { Manual } \\
\text { Mutu PT }\end{array}$ \\
\hline & EP-1.2 & Misi Prodi & $\begin{array}{l}\text { Manual } \\
\text { Mutu PT }\end{array}$ \\
\hline & EP-1.3 & $\begin{array}{l}\text { Tujuan dan } \\
\text { sasaran mutu }\end{array}$ & 5.1 \\
\hline & EP-1.4 & $\begin{array}{l}\text { Visi, misi, } \\
\text { tujuan dan } \\
\text { sasaran } \\
\text { didukung } \\
\text { pemangku } \\
\text { kepentingan } \\
\text { programstudi }\end{array}$ & $\begin{array}{l}\text { Manual } \\
\text { Mutu PT }\end{array}$ \\
\hline & EP-1.5 & $\begin{array}{l}\text { Strategi } \\
\text { pencapaian } \\
\text { sasaran bukti } \\
\text { tertulis dan } \\
\text { fakta lapangan }\end{array}$ & 5.1 \\
\hline
\end{tabular}

Selanjutnya dapat diberikan contoh mapping Standar Akreditasi BAN-PT kedalam ISO 9001:2008 untuk standar 1 terkait Mutu Kelembagaan ( Tabel 3) serta Standar 4 Sumber daya Manusia, pada Tabel 4.
Tabel 4.Mapping Standar Akreditasi BAN-PT ke ISO 900:2008 untuk Standar 4:Sumber Daya Manusia

\begin{tabular}{|c|c|c|c|}
\hline $\begin{array}{l}\text { Standar } \\
\text { Akreditasi }\end{array}$ & $\begin{array}{l}\text { Elemen } \\
\text { Penilaian }\end{array}$ & Deskripsi & $\begin{array}{l}\text { KlausaISO } \\
\text { 9001:2008 } \\
\end{array}$ \\
\hline \multirow[t]{7}{*}{ SA-4 } & $\begin{array}{l}\text { Sumber } \\
\text { Daya }\end{array}$ & $\begin{array}{l}\text { Sumber Daya } \\
\text { Manusia }\end{array}$ & 6.2 \\
\hline & $\begin{array}{l}\text { Manusia } \\
\text { EP-4.1 }\end{array}$ & $\begin{array}{l}\text { Kualifikasi } \\
\text { Akademik, } \\
\text { Kompetensi } \\
\text { dan jumlah } \\
\text { dosen }\end{array}$ & $\begin{array}{l}6.1 ; 6,2, \\
6.2 .2 ; 7.2 .1\end{array}$ \\
\hline & EP-4.2 & Prestasi Dosen & $\begin{array}{ll}6.1 ; & 6.2 ; \\
6.2 .2 & \end{array}$ \\
\hline & EP-4.3 & $\begin{array}{l}\text { Reputasi dan } \\
\text { keluasan } \\
\text { jejaring dosen }\end{array}$ & 6.2 .2 \\
\hline & EP-4.4 & $\begin{array}{l}\text { Jumah Ratio, } \\
\text { kualifikasi dan } \\
\text { kompetensi } \\
\text { tenaga } \\
\text { akademik }\end{array}$ & $\begin{array}{l}6.2 .1 \\
6.2 .2\end{array}$ \\
\hline & $\mathrm{EP}-4.5$ & $\begin{array}{l}\text { Ke-efektifan } \\
\text { sistem seleksi } \\
\text { rekrut, } \\
\text { penempatan,pe } \\
\text { ngembangan, } \\
\text { dan } \\
\text { pemberhentian } \\
\text { dosen dan } \\
\text { tenaga } \\
\text { kependidikan } \\
\text { buat menjanin } \\
\text { mutu }\end{array}$ & $\begin{array}{l}6.2 .2 \\
7.2 .1\end{array}$ \\
\hline & EP-4.6 & $\begin{array}{l}\text { Sistem } \\
\text { monitoring dan } \\
\text { evaluasi serta } \\
\text { rekam jejak } \\
\text { kinerja SDM }\end{array}$ & $\begin{array}{l}6.2 .1 \\
6.2 .2 \\
8.2 .3\end{array}$ \\
\hline
\end{tabular}

Selanjutnya secara keseluruhandapat dirangkum seperti pada Tabel 5 .

Tabel 5. Rangkuman Hasil Mapping Standar Akreditasi BAN-PT dengan ISO 9001:2008

\begin{tabular}{lll}
\hline $\begin{array}{l}\text { Standar } \\
\text { Akreditasi }\end{array}$ & $\begin{array}{l}\text { Jumlah } \\
\text { Elemen } \\
\text { Penilaian }\end{array}$ & $\begin{array}{l}\text { Jumlah elemen } \\
\text { penilaian yang bisa } \\
\text { mengadopsi klausa } \\
\text { dan persyaratan } \\
\text { ISO akreditasi } \\
\text { BAN-PT }\end{array}$ \\
\hline SA-1 & 5 & 2 \\
SA-2 & 8 & 8 \\
SA-3 & 8 & 8 \\
SA-4 & 6 & 6 \\
SA-5 & 11 & 11 \\
SA-6 & 6 & 6 \\
SA-7 & 9 & 9 \\
\hline Total & $\mathbf{5 3}$ & $\mathbf{5 0}$ \\
\hline
\end{tabular}

Pada cara mapping yang kedua ini yaitu Mapping ISO 9001:2008 kedalam Standar Akreditasi Program Studi BAN-PT harus dengan menggunakan faktor konfidensi. Bila faktor konfidensi bernilai 100 maksudnya bahwa kesesuainnya tepat dan bila tidak lengkap bernilai 60 
dari 30 inteprestasi Standar Akreditas BAN-PT mungkin bisa memenuhi persyaratan ISO. Sedangkan bila bernilai 30 dimaksudkan bahwa persyaratan ISO sama sekali tidak berkorespondesi dengan Standar Akreditas BAN-PT. Pada cara mapping yang disajikan disini sebagai contohnya untuk Klausa 6.0 ISO 9001:2008 terkait dengan pengelolaan sumber daya agar bisa membandingkan dengan mapping Standar BAN-PT ke ISO 9001:2008 terkait hal yang sama. Sumber Daya disini tidak hanya terkait dengan sumber daya manusia saja ( dosen dan tenaga kependidikan ), akan tetapi sarana prasarana serta lingkungan kerja atau sarana yang menyebabkan mutu dari suasana akademik.

Tabel 7.Mapping ISO ke Standar Akreditasi BAN-PT Klausa 6

\begin{tabular}{|c|c|c|c|c|}
\hline Klausa & $\begin{array}{l}\text { ISO } \\
9001: 2008\end{array}$ & $\begin{array}{l}\text { SA } \\
\text { BAN-PT }\end{array}$ & EP & FK \\
\hline 6.0 & $\begin{array}{l}\text { Pengeloaan } \\
\text { Sumber } \\
\text { Daya }\end{array}$ & & & \\
\hline \multirow[t]{3}{*}{6.1} & $\begin{array}{l}\text { Penyediaan } \\
\text { sumber daya }\end{array}$ & SA-4 & EP-4.1 & 100 \\
\hline & $\begin{array}{l}\text { Penerapan } \\
\text { dan } \\
\text { perbaikan } \\
\text { SMM }\end{array}$ & SA-4 & EP-4.1 & 100 \\
\hline & $\begin{array}{l}\text { Sumber daya } \\
\text { untuk } \\
\text { kepuasan } \\
\text { pelanggan }\end{array}$ & SA-4 & $\begin{array}{l}\text { EP-4.1 } \\
\text { EP-4.2 } \\
\text { EP-4.3 }\end{array}$ & $\begin{array}{l}100 \\
100 \\
100\end{array}$ \\
\hline 6.2 & $\begin{array}{l}\text { Sumber daya } \\
\text { manusia }\end{array}$ & SA-4 & EP-4.0 & 100 \\
\hline \multirow[t]{2}{*}{6.2 .1} & Umum & & EP-4.4 & 100 \\
\hline & $\begin{array}{l}\text { Memerlukan } \\
\text { ketrampilan }\end{array}$ & SA-4 & EP-4.5 & 100 \\
\hline \multirow[t]{2}{*}{6.2 .2} & $\begin{array}{l}\text { Kompetensi, } \\
\text { pelatihan dan } \\
\text { kesadaran }\end{array}$ & SA-4 & EP-4.2 & 100 \\
\hline & $\begin{array}{l}\text { Kompetensi, } \\
\text { pelaatihan, } \\
\text { keefektifan, } \\
\text { kedaran,me } \\
\text { melihara } \\
\text { rekaman }\end{array}$ & SA-4 & $\begin{array}{l}\text { EP-4.2 } \\
\text { EP-4.5 } \\
\text { EP-4.6 }\end{array}$ & $\begin{array}{l}100 \\
100 \\
100\end{array}$ \\
\hline 6.3 & $\begin{array}{l}\text { Prasarana } \\
\text { Penyediaan } \\
\text { Layanan dan } \\
\text { peralatan }\end{array}$ & SA-6 & $\begin{array}{l}\text { EP-6.5 } \\
\text { EP-6.6 }\end{array}$ & 100 \\
\hline 6.4 & $\begin{array}{l}\text { Lingkungan } \\
\text { Kerja } \\
\text { Memelihara } \\
\text { lingkungan } \\
\text { kerja yang } \\
\text { sesuai } \\
\text { dengan } \\
\text { persyaratan }\end{array}$ & SA-5 & EP-5.11 & 100 \\
\hline
\end{tabular}

Secara menyeluruh dari 8 Klausa ISO 9001 :2008, maka semua hasil mapping-nya dapat dirangkum seperti Tabel 8.
Tabel 8. Rangkuman Hasil Mapping ISO 9001:2008 Dan Standar Akreditasi BAN-PT

\begin{tabular}{lll}
\hline Klausa & $\begin{array}{l}\text { Jumlah Klausa } \\
\text { dan sub klausa }\end{array}$ & $\begin{array}{l}\text { Jumlah klausa yang } \\
\text { bisa } \\
\text { kembali } \begin{array}{r}\text { digunakan } \\
\text { akreditasiam }\end{array} \\
\text { BAN-PT }\end{array}$ \\
\hline 4.0 & 5 & 4 \\
5.0 & 11 & 10 \\
6.0 & 5 & 5 \\
7.0 & 20 & 17 \\
8.0 & 10 & 10 \\
\hline Total & $\mathbf{5 1}$ & $\mathbf{4 6}$ \\
\hline
\end{tabular}

\section{Model Harmonisasi :}

Dengan berdasarkan hasil komparasi dan mapping sebelumnya maka digunakan model harmonisasi yang didasarkan pada teori himpunan[7]. Tujuannya untuk menghimpun Elelem Penilaian dalam stnadar akreditasi mana yang bisa atau tidak mengadopsi bagian bagian ISO atau juga klausa mana yang dapat digunaka kembali ketika program studi akan melaksanakan akreditasi BAN-PT.

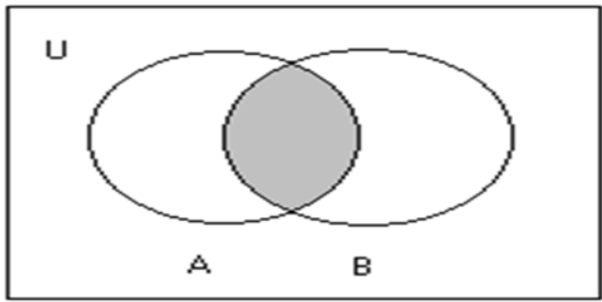

Gambar 3. Operasi Interksi ISO dan BAN-PT

Dalam himpunan terdapat operasi interseksi, dimana tujuannya untuk menyatakan hasil integrasi akreditasi BAN-PT dan ISO 9001:2008.

$\mathrm{A} \cap \mathrm{B}=\{\mathrm{x} \mid \mathrm{x} \in \mathrm{A}$ dan $\mathrm{x} \in \mathrm{B}\}$

dimana :

$\mathrm{x}=$ Elemen peninalian dslam SA BAN-PT dan kluasa dan sub klausa ISO

$\mathrm{A}=$ Himpunan EP dalam standar akreditasi BAN-PT $\mathrm{n}(\mathrm{A})=53$ atau terdapat 53 elemen penilaian dalam standard akreditasi BAN-PT

B = Himpunan klausa dalam ISO 9001:2008

$\mathrm{n}(\mathrm{B})=51$ atau terdapat 51 klausa berserta persyaratan ISO 9001:2008

$\mathrm{U}=$ Himpunan semua klausa ISO dan Elemen Penilaian Standar Akreditasi BAN-PT yang terkait model Sistem Penjaminan Mutu

Misal: $\mathrm{A}=\{\mathrm{x} \mid \mathrm{x}=$ standar akreditasi dalam BAN-PT $\}$ $\mathrm{B}=\{\mathrm{x} \mid \mathrm{x}=$ bagian klausa dari ISO $\}$

Maka $\mathrm{n}(\mathrm{A} \cap \mathrm{B})=50$. Jadi terdapat 50 Elemen Penilaiain standard akreditasi berelasi kuat dan yang 
bisa mengadopsi klausa ISO 9001: 2008. Khusus untuk Sistem Penjaminan Mutu, seperti yang ditunjukkan SA-1, yaitu pada EP-1.1, EP-1.2, dan EP-1.4 tidak pada gambar 6. terpenuhi dalam ISO, karena terkait visi dan misi yang ada dalam Manual Mutu bukan dimilki program studi akan tetapi dimiliki oleh Institusi. Inilah yang dianggap tidak berelasi kuat dengan ISO. Operasi Selisih dalam teori himpunan ini juga dapat untuk menyatakan Standard Akeditasi mana yang tidak dapat mengadopsi persyaratan ISO 9001: 2008.

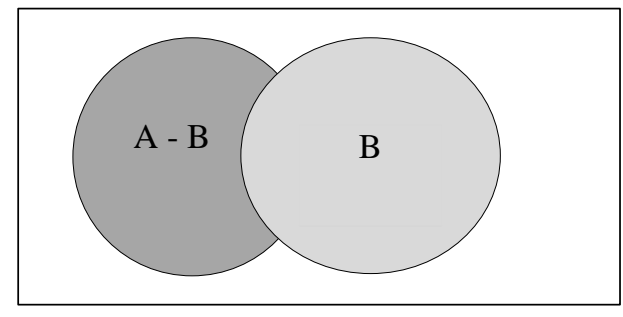

Gambar 4. Operasi Selisih BAN-PT dan ISO

Dinyatakan: $\mathrm{A}-\mathrm{B}=\{\mathrm{x} \mid \mathrm{x} \in \mathrm{A}$ dan $\mathrm{x} \notin \mathrm{B}\}$

$\mathrm{A}-\mathrm{B}=\{\mathrm{EP}-1.1, \mathrm{EP}-1.2, \mathrm{EP}-1.4\} \rightarrow \mathrm{n}(\mathrm{A}-\mathrm{B})=3$

Jadi Standar Akreditasi dalam Akreitasi BAN-PT yang tidak bisa mengadopsi peryaratan ISO 9001:2008 adalah SA-1 khususnya pada EP-1, EP-2 dan EP-4. Operasi selisih lain, dalam teori himpunan ini juga untuk menyatakan bagian dan klausa ISO 9001: 2008 yang tidak dapat diadopsi dalam penerapan standar akreditasi

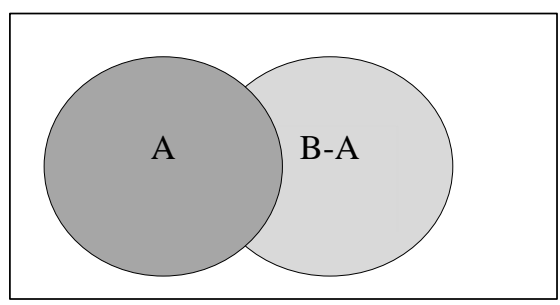

Gambar 5. Operasi Selisih ISO dan BAN-PT

Dinyatakan dengan : $\mathrm{B}-\mathrm{A}=\{\mathrm{x} \mid \mathrm{x} \in \mathrm{B}$ dan $\mathrm{x} \notin \mathrm{A}\}$

Maka B- A = \{(4.2.2), (5.5.2), (7.4.1), (7.4.2), (7.4.3) $\}$ $\rightarrow \mathrm{n}(\mathrm{B}-\mathrm{A})=5$

Jadi klausa ISO 9001:2008 yang tidak bisa diadopsi dalam Standar Akreditasi BAN-PT adalah klausa kepentingan/pelanggan (7.2.3), disain pengembangan (4.2.2) Manual Mutu yang tidak dimiliki program studi, (7.3) serta produksi dan penyediaan jasa (7.5) Pada klasusa (5.4.2)wakil manajemen (Manajemen Proses $\boldsymbol{C H E C K}$, maka harus dipenuhi sub Klausa 8.2 ( Reprentative) yang merupakan pimpinan Biro Kendali Measurement Analysis) antara lain : Kepuasan Mutu Institusi dan terkait proses pembelian yaitu Pelanggan (8.2.1), audit internal (8.2.2), pemntauan dan klausa (7.4.1), (7.4.2), (7.4.3) yang dilakukan oleh pengukuran(8.2.3) serta pemantauan dan pengukuran Bagian Pengadaan Barang dalam organisasi institusi.

\section{Penerapan Konsep PDCA :}

Pengembangan Model Sistem Penjaminan Mutu Berbasis Integrasi Akreditasi BAN-PT dan ISO 9001:2008 didasarkan pada prinsip proses Plan-DoCheck-Action yang berkesesuain. Kerangka Kerja

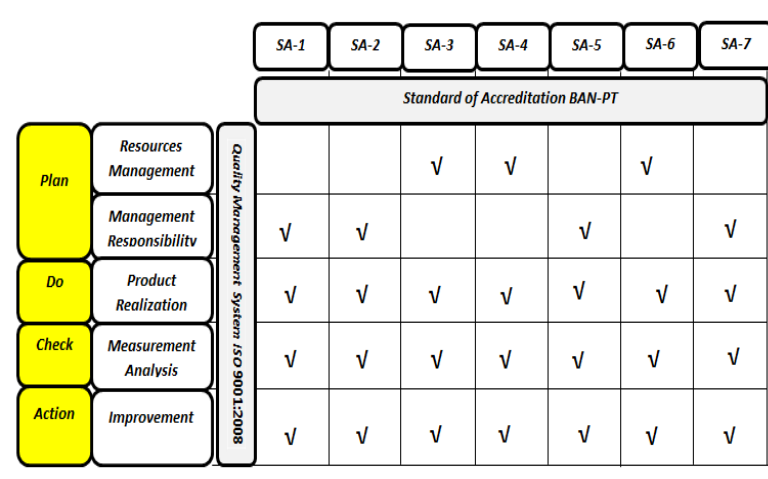

Gambar 6. Quality Management System Framework

Kerangka kerja sistem penjaminan mutu ( Quality proses-proses utama yaitu Perencanaan ( PLAN ), Pelaksanaan (DO), Evaluasi dan Audit ( CHECK ) dan Perbaikan dan Peningkatan ( $\boldsymbol{A C T I O N}$ ). Untuk setiap proses nantinya diberlakukan untuk setiap Standar Mutu dalam Akreditasi BAN-PT yang jumlah sebanyak 7 standard akreditasi. Kesesuaian antar proses berdasarkan PDCA ISO sebagai berikut:

\section{ISO 9001:2008 :}

a. Klausa 6 ( Resources Management ), yaitu Penyediaan Sumber Daya (6.1), sumber daya manusia (6.2), Prasarana (6.3) dan lingkungan kerja (6.4)

b. Klausa 5 ( Management Responsibilty ), yaitu : Komitmen Manajemen (5,1), Fokus Pelanggan (5.2), Kebijakan Mutu (5.3), Perencanaan (5.4), Tanggung jawab,wewenang dan komunikasi (5.5) serta Tinjauan Manajemen (5.6)

Pada Proses DO, maka dijalankan sesuai Klausa 7 ( Product Realization) antara lain : perencanaan realisasi produk dengan berbagai persayaratannya (7.1) penetapan persyaratan (7.2.1), tujuan persayaratan (7.2.2), komunikasi dengan pemangku produk (8.2.4). Pada Proses ACTION, maka dijalankan sesuai sub klausa Klausa 8.5 ( Improvement ) antara lain : Perbaikan berkesinambungan (8.5.1), tindakan korektif (8.5.2) serta tindakan pencegahan(8.5.3) Management System Framework ) akan memiliki 


\section{Standar Akreditasi BAN-PT :}

Pada proses $\boldsymbol{P L A N}$, maka akan dipenuhi oleh :

a. Tanggung Jawab Manajemen dalam penyelenggaran program studi yaitu : SA-1 yaitu Tujuan dan sasaran yang relevan dengan visi dan misi (EP-1.3), Strategi pencapaian sasaran mutu (EP-1.5) SA-2 yaitu EP-2.1, EP-2.2, EP-2.3, Komitmen Manajemen SA-2 yaitu EP-2.1, EP-2.2, EP-2.3, Fokus Pelanggan (5.2), Kebijakan Mutu (EP-5.11), Perencanaan kurikulum (EP-5.5), Tanggung jawab,wewenang dan komunikasi (EP2.3) serta Tinjauan Manajemen (EP-5.4)

b. Perencanaan Sumber Daya : SA-4 yaitu Kualifikasi, komptensi dan jumalh dosen (EP-4.1), Prestasi dosen (EP-4.2), reputasi dan keluasan jejaring dosen (EP-4.3)Jumlah dan kualifikasi tenaga akademik (EP-4.4), Pembiayaan (EP-6.1, EP-6.2), Sarana (EP-6.3, EP-6.4)dan prasarana (EP-6.5)dan sistem informasi (EP-6.6)

Pada Proses $\boldsymbol{D} \boldsymbol{O}$, maka dijalankan :

Standar Mutu terkait realisasi produk antara lain kurikulum (EP-5.1, EP-5.2, EP-5.3 ) lulusan (EP-3.5, EP-3.6) penelitian(EP-7.1, EP-7.2, EP-7.3, EP-7.4, EP7.5), proses yang berkaitan dengan pembelajaran, disain dan pengembangan kurikulum serta produktivitas (lulusan dan penelitian (EP-7.7) dan penyediaan jasa (pengabdian masyarakat (EP-7.8) dan kerjasama(EP-7.9) dan pengendalian pemantauan dan pengukuran produk ( sistem penjaminan mutu (EP-2.7, EP-2.8) dan sistem Informasi(EP-6.6 )

Pada Proses $\boldsymbol{C H E C K}$, maka dijalankan sesuai elemen penilaian dalam Standar Mutu antara lain : Kepuasan Pelanggan (EP-3.4, EP-3.6, EP7.8), audit internal (EP2.8), pemantauan dan pengukuran (EP-1.3, EP-5.7) serta pemantauan dan pengukuran produk lulusan dan penelitian (EP-4.6)

Pada Proses ACTION, maka dijalankan sesuai elemen penilaian dalam Standar Mutu) antara lain :

Perbaikan berkesinambungan (EP-7.2) untuk proses Pembelajaran, mahasiswa,dosen, tenaga pendidikan), tindakan korektif (EP7.8) masukan dari penilaian mahasiswa dan pengguna lulusan) serta tindakan pencegahan (EP-2.2) dengan mengakomodasi semua unsur.

Hasil penelitian ini kedepannya dikembangkan sampai pembuatan model Sistem Informasi Penjaminan Mutu untuk Program Studi untuk perguruan tinggi bersertifikasi ISO.

\subsection{Pembahasan}

Pembahasan disini mencakup bahasan terkait evaluasi hasil integrasi dengan beberapa metode, evaluasi efektivitas pelaksanaan Standar Akreditasi Program Studi BAN-PT, evaluasi efisiensi penggunaan kembali klausa ISO dalam pelaksanan akreditasi BAN-PT serta evaluasi hasil validitas integrasi

Berdasarkan hasil mapping Standar Akreditasi Program Studi BAN-PT ke dalam ISO 9001:2008 maka evaluasi efektivitas pelaksanaan Standar Akreditasi Program Studi BAN-PT pada Perguruan Tinggi bersertifikasi ISO dapat ditentukan :

Efektivitas Elemen Penilaian Standar Akreditasi dalam mengadopsi Klausa ISO

Efektivitas $(\%)=\left(\sum \mathrm{x} / \sum \mathrm{y}\right) \times 100 \%$

dimana :

$\mathrm{x}=$ jumlah EP yang bisa mengadopsi klausa ISO

$\mathrm{y}=$ jumlah total EP standar akreditasi BAN-PT

Maka, efektivitas Elemen Penilaian Standar Akreditasi dalam mengadopsi Klausa ISO

$=(50 / 55) \times 100 \%=\mathbf{9 0 , 9 1 \%}$

Berdasarkan hasil mapping Standar Akreditasi Program Studi BAN-PT ke dalam ISO 9001:2008 maka evaluasi efisiensi penggunaan kembali klausa dan persyaratan ISO 9001;2008 dalam pelaksanaan Standar Akreditasi Program Studi BAN-PT pada Perguruan Tinggi bersertifikasi ISO dapat ditentukan :

Efisiensi $(\%)=\left(\sum a / \sum b\right) \times 100 \%$

dimana :

$\sum \mathrm{a}=$ jumlah klausa ISO yang bisa digunakan kembali

$\sum \mathrm{b}=$ jumlah total klausa ISO 9001:2008

Maka, efisiensi penggunaan kembali klausa ISO dalam penerapan akreditasi BAN-PT

$=(46 / 51) \times 100 \%=\mathbf{9 0 , 2 0 \%}$

Hasil Focus Group Discussion dengan Dekan dan Para Kaprodi, ternyata menyatakan perlu nya sekali Sistem Penjamin Mutu untuk Internal Program Studi yang berbasis integrasi akreditasi BAN-PT dan ISO 9001:2008 sehingga pelaksanaannya akan lebih efektif dan efisien. Hasil intergrasi penerapan Standar Akreditasi Program Studi BAN-PT dan ISO 9001:2008 selanjunyta dilakukan uji validitas dan suatu pengujian konfirmabilitas yang dilakukan oleh asesor BAN-PT dan Auditor ISO 9001:2008, dimana dalam uji mereka diposisikan sebagai verifikator. Berdasarkan hasil uji ini didapatkan hasil bahwa $80 \%$ verifikator menyatakan "confirm" atas model yang dikembangkan ini.

Pengembangan Model Sistem Penjaminan Mutu Berbasis Integrasi Akreditasi BAN-PT dan ISO 9001:2008 didasarkan pada prinsip Proses Plan-DoCheck-Action yang berkesesuain, yang nantinya akan mempermudah dalam mendisain pemodelan sistem informasinya pada tahap selanjutnya dimasa mendatang. 
Hasil penerapan Model Sistem Penjaminan Model Penjaminan Mutu Program Studi untuk Perguruan berbasis integrasi Standar Akreditasi Program Studi Tinggi bersertifikasi ISO hingga memperoleh Hak BAN-PT dan ISO 9001:2008 memiliki implikasi dari Paten pada tahap akhirnya. Harapannya, model penelitian sisi teortis, teknis dan managerial. Secara teoritis, hasil ini akan menjadi alat yang sangat berguna untuk perguruan penelitian ini mewujudkan Sistem Penjaminan Mutu tinggi bersertifikat ISO yang berencana menerapkan Internal dari setiap program studi. Implikasi Teknis Akreditasi BAN-PT.

penerapan model integrasi khususnya terkait ketika saat pelaksanaan akreditasi dengan menerapkan konsep PDCA dari ISO 9001:2008. Implikasi ini didasarkan proses-proses PDCA sebagai bagian dari Sistem Penjaminan Mutu yang dihasilkan. Implikasi managerial terkait hasil integrasi akreditasi BAN-PT dan ISO 9001:2008 maka Perguruan Tinggi bersertifikasi ISO ketika melaksnakan akreditasi akan lebih efisien dalam menggunakan kembali sumber daya yang ada, selanjutnya efektif kinerjanya untuk mencapai keberhasilan akreditasi program studi. Agar tercapainya ini semua diharapkan program studi membentuk bidang Penjaminan Mutu yang merupakan sinergi dari Biro Kendali Mutu yang dimiliki Perguruan Tinggi.

\section{Kesimpulan}

Berdasarkan hasil integrasi Akreditasi Program Studi BAN-PT dengan ISO 9001:2008 dalam penelitian ini maka dapat diberikan kesimpulan dan saran.

\subsection{Simpulan}

a. Penerapan Standar Akreditasi Program Studi BANPT, yaitu dengan melakukan komparasi dan mapping dan harmonisasi model antara elemen penilaian (EP) pada Standar Akrediatsi dengan bagian-bagian klausa ISO yang sesuai, dimana hasilnya sebesar 90,91 \% Elemen Penilaian pada Standar Akreditasi dapat mengadopsi persayaratanpersayaratan ISO 9001:2008 sehingga dapat meningkatkan kinerja ( performance ) Program Studi pada Perguruan Tinggi bersertifikasi ISO saat pelaksanaan akreditasi dengan lebih efektif

b. Penggunaan kembali bagian-bagian klausa serta persyaratan yang dipilih dari standar ISO 9001:2008, dengan melakukan komparasi, mapping dan harmonisasi model, antara klausa yang ada dalam ISO dengan elemen penilaian Standard Akreditasi sehingga didapat hasil efisiensi penggunaan kembali klausa $\mathbf{9 0 , 2 0 \%}$, sehingga dengan hasil ini maka penggunaan sumber daya (resource) Pergiruan Tinggi, khususnya Program Studi akan dapat lebih efisien saat pelaksanaan akreditasi

\subsection{Saran}

Hasil integrasi ISO 9001:2008 dan Akreditasi BAN-PT berupa kerangka kerja sistem penjaminan mutu yang dihasilkan dalam penelitian ini, tahap selanjutnya bisa dikembangkan kedalam Pemodelan Sistem Informasi Penjaminan Mutu Perguruan Tinggi. Pada tahap berikutnya, dalam bentuk Aplikasi Sistem Informasi

\section{Daftar Rujukan}

[1] Badan Akreditasi Nasional Perguruan Tinggi (BAN-PT), 2015. Akreditasi Program Studi [Online].Available at: http://banpt.kemdiknas.go.id/rasional.[Accessed 2 Nopember 2016]

[2] Riset Teknologi dan Pendidikan Tinggi (Ristek Dikti) 2010. Sistem Penjaminan Mutu Pergutuan Tinggi (SPM-PT). [Online]. Available at: http://spmi.ristekdikti.go.id/klinikspmi/downloadtutorial/21. [Accessed 1 Jumi 2017]

[3] Internasional Standard for Organization (ISO), 2008. SNI ISO 9001:2008 [Online]. Available at: http://www.iso.org/iso/catalog_detail,. [Accessed 2 Januari 2017]

4] Ryan, Tricia." Quality Assurance in Higher Education: A Review of Literature". Higher Learning Research Communications Journal, Volume 5, No. 4 December 2015.

[5] Paulk, C.Mark "How ISO 9001 Compares With The CMM, IEEE Software, Vol 12, No.1 p74-92, January, 1995

[6] Mutafelija, B and Stromberg, H, "Process Improvement with $C M M I^{\circledR}, v 1.2$ and ISO Standard, CRC Press, Taylor and Franciss Group.2009

7] Pardo, Cesar.,Pino J.Francisco., Garcia, Felix., Platini, Mario Arcia, "Identifying Methods and Technique for the Harmozation of the Multiple Process References Model, $5^{\text {th }}$ International Conference on Evaluation of Novel Approaches to Software Engineering-ENASE2010, Athens, Greece, ISSN 0012-7353, 2012

[8] H. Asy'ari, "Perbandingan Sistem Manajemen Mutu ISO 9001:2008, Standard BAN-PT dan Total Quality Management di UIN Maulana Malik Ibrahim Malang”. Jurnal Pendidikan Islam ,Volume IV, Nomor 1, Juni 2015/1436, pp.141-157, 2015

[9] T.W Soerjaningsih," Peningkatan Mutu Proses Perguruan Tinggi Melalui Sistem Mutu ISO 9001". Journal The WINNERS, Vol. 5 No. 2, September 2004: pp. 79-89

10] T. Chandrawati, S.Puspitasari dan Jasrial, "Pengaruh Pencapaian ISO 9001:2000 Terhadap Peningkatan Kualitas Layanan Belajar Jarak Jauh di 11 UPBJJ-UT". Jurnal Pendidikan Terbuka dan Jarak Jauh, Volume 10, Nomor 2, September 2009, pp.84-99

[11] R.Renaldi, Sholiq, dan F.A Muqtadiroh, "Rancang Bangun Perangkat Lunak Sistem Pendokumentasian Kegiatan penelitian, Pelayanan/Pengabdian Masyarakat dan Sistem Kerjasama untu Pengembangan Sistem Informasi Terintegrasi Sesuai Kebutuhan Pengisian Borang Akreditasi BAN-PT pada Jurusan Sistem Informasi, Jurnal Teknik POMITS Vol. 1, No. 1. 2013. pp1-6

[12] Yoo. Chanwo, Yoon. Junho, Lee. Byungjeong, Lee. Chongwon, Lee. Jinyong, Hyun. Seunghun and Wu.Chisu. "A Unified Model for The Implementation of both ISO 9001:2001 and CMMI by ISO Certfied Organisastion". Journal of System and Software. Vol.79. No.1. Elseiver inc. 2006.

[13] Robert C. Bogdan dan Steven J. Taylor, Introduction to Qualitative-Research methods, New York: John Wiley \& Sons, 1975), pp.4

[14] Mattew B. Miles \& Huberman, Analisis Data Kualitatif, (Jakarta: UI-Press., 1992), pp 15. 